\title{
Effects of Bacillus megatherium 1259 on Growth Performance, Nutrient Digestibility, Rumen Fermentation, and Blood Biochemical Parameters in Holstein Bull Calves
}

\author{
Bobo Deng ${ }^{1}$, Yinyin Chen ${ }^{1}$, Xiaoxiao Gong ${ }^{1}$, Yi Dai ${ }^{1}$, Kang Zhan ${ }^{1}$, Miao Lin ${ }^{1}$, Lin Wang ${ }^{2,3}$ and \\ Guoqi Zhao 1,2,3,*
}

1 College of Animal Science and Technology, Yangzhou University, Yangzhou 225009, China; 18168960899@163.com (B.D.); chenyinyin90s@163.com (Y.C.); 18762329160@163.com (X.G.); cminghui93@gmail.com (Y.D.); zhankang0305@163.com (K.Z.); linmiao3025@163.com (M.L.)

2 Institutes of Agricultural Science and Technology Development, Yangzhou University, Yangzhou 225009, China; michelle861215@hotmail.com

3 Joint International Research Laboratory of Agriculture and Agri-Product Safety, The Ministry of Education of China, Yangzhou University, Yangzhou 225009, China

* Correspondence: gqzhao@yzu.edu.cn; Tel.: +86-514-879-72-208

\section{check for} updates

Citation: Deng, B.; Chen, Y.; Gong, X.; Dai, Y.; Zhan, K.; Lin, M.; Wang, L.; Zhao, G. Effects of Bacillus megatherium 1259 on Growth Performance, Nutrient Digestibility, Rumen Fermentation, and Blood Biochemical Parameters in Holstein Bull Calves. Animals 2021, 11, 2379. https://doi.org/10.3390/ani 11082379

Academic Editor: Irina Garcia Ispierto

Received: 13 July 2021

Accepted: 10 August 2021

Published: 12 August 2021

Publisher's Note: MDPI stays neutral with regard to jurisdictional claims in published maps and institutional affiliations.

Copyright: (c) 2021 by the authors. Licensee MDPI, Basel, Switzerland. This article is an open access article distributed under the terms and conditions of the Creative Commons Attribution (CC BY) license (https:// creativecommons.org/licenses/by/ $4.0 /)$.
Simple Summary: This study was conducted to investigate the effects of dietary supplementation with Bacillus megaterium 1259 (BM1259) on growth performance, nutrient digestibility, rumen fermentation, and blood biochemical parameters in Holstein bull calves. The results demonstrated that the addition of BM1259 to the diets can significantly improve the growth performance and elevate the apparent digestibility of crude protein and neutral detergent fiber. Moreover, supplementation with BM1259 ameliorated rumen fermentation and reduced the emission of both ammoniacal nitrogen and sulfuretted hydrogen in feces and urine. In addition, adding $12 \mathrm{~g} /$ head/day of BM1259 had no adverse effect on blood biochemical parameters and the health status of Holstein bull calves. This study demonstrates that BM1259 can be applied as a potential microecologics to improve production performance and nitrogen utilization in Holstein bull calves.

Abstract: Bacillus megaterium is an ideal microecologics in the feed industry. BM1259 was already isolated from chicken manure and the whole-genome sequencing was also analyzed in our previous study. However, few studies concentrated on dietary supplementation with BM1259 in young ruminants and especially its effect on Holstein bull calves have not been reported. Hence, this experiment was conducted with the aim to evaluate the effects of BM1259 on growth performance, nutrient digestibility, rumen fermentation, and blood biochemical parameters in Holstein bull calves. Twenty-four healthy Holstein bull calves with the initial age of 90 days old and a similar body weight $(115 \pm 6.5 \mathrm{~kg})$ were selected and randomly allocated into two groups with one Holstein bull calf in each pen $(2.5 \mathrm{~m} \times 2.2 \mathrm{~m})$. Holstein bull calves in the control group (COG) were fed a basal total mixed ration (TMR), while experimental treatments (BMG) were fed with the TMR diet supplemented with $12 \mathrm{~g} /$ head/day of BM1259 powder $\left(1 \times 10^{10} \mathrm{cfu} / \mathrm{g}\right)$ separately. Results showed that (1) the average daily gain and dry matter intake of the BMG were significantly higher than those of the COG $(p<0.01)$, increased by $12.5 \%$ and $8.79 \%$, respectively, during the $4-8$ weeks after the addition of $12 \mathrm{~g} /$ head/day of BM1259; from 0 to 8 weeks, ADG $(p<0.05)$ and DMI $(p<0.05)$ in the BMG were significantly higher than those in the COG, increased by $14.9 \%$ and $6.04 \%$, respectively. (2) At the end of the fourth week, the apparent digestibility of crude protein and neutral detergent fiber in the BMG was significantly higher than that in the COG $(p<0.05)$, increased by $5.97 \%$ and $6.70 \%$, respectively; at the end of the eighth week, the apparent digestibility of crude protein and neutral detergent fiber was significantly higher than that of the COG $(p<0.01)$, increased by $5.88 \%$ and $10.26 \%$, respectively. (3) At the end of the eighth week, the rumen fluid $\mathrm{pH}(p<0.05), \mathrm{MCP}(p<0.05)$, and acetate $(p<0.05)$ in the BMG were significantly higher than those in the COG, increased by $9.03 \%$, $19.68 \%$, and $12.74 \%$, respectively; at the end of the fourth and eighth week, $\mathrm{NH}_{3}-\mathrm{N}$ concentration in the BMG was significantly lower than that in the COG, with a decrease of $21.81 \%$ and $16.40 \%$, respectively. (4) At the end of the fourth $(p<0.05)$ and eighth week $(p<0.05)$, the glutamate content 
of the rumen fluid of the Holstein bull calves in the BMG was significantly higher than that in the COG, increased by $13.21 \%$ and $14.32 \%$, respectively; at the end of the fourth week, the contents of glutamate in the serum $(p<0.05)$, urine $(p<0.05)$, and feces $(p<0.05)$ of the Holstein bull calves in the BMG were significantly lower than those in the COG, decreased by $25.76 \%, 33.87 \%$, and $9.23 \%$, respectively; at the end of the eighth week, the contents of glutamate in the serum, urine, and feces of the Holstein bull calves in the BMG were significantly lower than those in the COG ( $p<0.01$ ), decreased by $26.69 \%, 27.94 \%$, and $11.11 \%$, respectively. (5) After adding $12 \mathrm{~g} / \mathrm{head} /$ day of BM1259, the urine ammonia-nitrogen content of the BMG was extremely significantly lower than that of the COG at the end of the fourth and eighth week $(p<0.01)$, decreased by $54.60 \%$ and $40.31 \%$, respectively. (6) After adding $12 \mathrm{~g} /$ head/day of BM1259, there was no significant effect on the level of blood biochemical parameters of the Holstein bull calves. This study demonstrates that BM1259 can be applied as a potential microecologics to improve growth performance, nutrient digestibility, rumen fermentation, and nitrogen utilization in Holstein bull calves.

Keywords: Bacillus megaterium 1259; growth performance; nutrient digestibility; rumen fermentation; blood biochemical parameters; Holstein bull calves

\section{Introduction}

In recent years, research and application of microecologics has attracted extensive attention from scholars in domestic fields and abroad. As a new kind of green and environmental protection feed additive, microecologics have been widely used in animal husbandry due to its green, safe, and residue-free function, which can be used to replace antibiotics, to promote the healthy growth of animals, and improve the environment $[1,2]$. At present, lactic acid bacteria, bacillus, yeast, photosynthetic bacteria, and so on are the most widely studied microecological additives. Among them, bacillus has a history of more than 100 years since its discovery and a large quantity of scientific research data have confirmed the use effect of bacillus [3]. Among bacillus, Bacillus megatherium as probiotics has become a research hotspot due to its unique characteristics, such as its strong resistance to stress, high temperature resistance, and easy storage [4,5]. BM1259, as a new-type of microecological additive isolated from chicken manure, is a gram-positive bacterium that can produce spores. BM1259 is usually a rode-shaped bacterium with rounded ends and tends to be arranged in single or chain forms. It is a large bacterium with a diameter of more than $1.0 \mu \mathrm{m}$ and a volume of more than 60 microcubic meters, which is 100 times the volume of E. coli, demonstrating strong resistance to high temperature treatment, ultraviolet radiation, drying, and high concentrations of organic solvents. It plays a very important role in improving animal production performance and product quality, increasing the output of livestock products and reducing feed costs [6-10]. Kritas et al. demonstrated that supplementing ewe feed with bacillus sp. probiotics promoted subsequent milk with yields, fat, and protein contents [11]. Huo et al. showed that feeding $0.04 \%$ of BM1259 could improve the digestibility of crude protein and dry matter in the diet of finishing pigs, reduce the production of $\mathrm{NH}_{3}$, and improve the air environment of pig pens to a certain extent [12]. Ding et al. added $100 \mathrm{mg} / \mathrm{kg}$ BM1259 to the feed of laying hens and found that the parameters of the total egg weight, egg number, and average egg weight were significantly increased, while the contents of ammonia-nitrogen, uric acid, and urea nitrogen in the excrement were significantly decreased, which could improve economic benefits [13]. Yu et al. supplemented $12 \mathrm{~g} /$ head/day of BM1259 to the diet of dairy cows, finding that the concentrations of urea nitrogen and uric acid in feces decreased, the activities of urease and uricase decreased, and the activity of alanine aminotransferase in the serum also decreased [14].

However, few studies concentrated on dietary supplementation with BM1259 in young ruminants and especially the study and application of BM1259 on Holstein bull calves is still unknown. Hence, this work was conducted with the aim to evaluate the effects of 
BM1259 on growth performance, nutrient digestibility, rumen fermentation, and blood biochemical parameters in Holstein bull calves. Together, these data could represent a useful basis for future applications of BM1259 as ruminant microecologics.

\section{Materials and Methods}

\subsection{Ethical Considerations}

All Holstein bull calves used in this study were strictly cared in accordance with the principles of Yangzhou University, the Institutional Animal Care, and the Use Committee (SYXK (Su) IACUC 2016-0019).

\subsection{Experimental Design, Animals, Diets, and Feeding Management}

The experiment was conducted at the Ruminant Experiment Research Farm, Yangzhou University (China), from April to July 2020. Twenty-four healthy Holstein bull calves of 90 days old with similar body weights $(115 \pm 6.5 \mathrm{~kg})$ were selected and randomly allocated into two groups with 12 replicates in each group and 1 Holstein bull calf in each pen $(2.5 \mathrm{~m} \times 2.2 \mathrm{~m})$. Holstein bull calves in the control group were fed a basal total mixed ration (TMR) without BM1259 and the BMG were fed with the TMR supplemented with $12 \mathrm{~g} / \mathrm{head} /$ day (recommended dose for the preliminary experiment) BM1259 powder $\left(1 \times 10^{10} \mathrm{cfu} / \mathrm{g}\right)$ separately. TMR were adjusted as isonitrogenous and isoenergetic diets (Table 1). The basal diets were formulated to meet or exceed the nutritional requirements and feeding standards of NRC (2001) cows. During the whole experiment period, all Holstein bull calves were given ad libitum access to TMR and fresh tap water. The pen was disinfected before the experiment began. Holstein bull calves were fed twice at 8:00 am and 17:00 pm each day. Daily feed allocations to each pen were adjusted according to the minimal feed refusals $(<10 \%)$ in the feed bunk and the weight of the residual was recorded every day before new feeding was delivered. This experiment consisted of a 14-day adaptation and a 56-day fattening period for sample collection.

Table 1. Basal diet formulations and nutritional contents (DM basis \%).

\begin{tabular}{|c|c|c|c|}
\hline Items & Content & Nutrient Levels (2) & Content \\
\hline Ground corn & 23.79 & $\mathrm{ME}(\mathrm{MJ} / \mathrm{kg})$ & 11.93 \\
\hline Wheat bran & 10.49 & $\mathrm{DM}(\%)$ & 89.18 \\
\hline Spray corn husk & 3.49 & $\mathrm{CP}(\% \mathrm{DM})$ & 18.85 \\
\hline Soybean meal (46\%) & 10.35 & $\mathrm{EE}(\% \mathrm{DM})$ & 3.22 \\
\hline DDGS (corn) & 7.00 & NDF (\%DM) & 41.08 \\
\hline Corn germ meal & 7.00 & $\mathrm{ADF}(\% \mathrm{DM})$ & 19.13 \\
\hline Soybean hull & 3.50 & Calcium (\%DM) & 0.85 \\
\hline Salt & 0.35 & Phosphorus (\%DM) & 0.41 \\
\hline Calcium carbonate & 1.23 & Glu (\%DM) & 1.69 \\
\hline Oat hay & 30.00 & & \\
\hline Premix ${ }^{(1)}$ & 2.80 & & \\
\hline Total & 100.00 & & \\
\hline
\end{tabular}

Abbreviations: DDGS, distiller dried grains with soluble; ME, metabolic energy; DM, dry matter; CP, crude protein; EE, ether extract; NDF, neutral detergent fiber; ADF, acid detergent fiber; and Glu, glutamate. ${ }^{(1)}$ Premix was formulated to provide (per kilogram of the dietary DM) $60.5 \mathrm{mg}$ of $\mathrm{Zn}$ as $\mathrm{ZnSO} 4 \cdot 7 \mathrm{H}_{2} \mathrm{O} ; 58.5 \mathrm{mg}$ of Mn as $\mathrm{MnSO}_{4} \cdot \mathrm{H}_{2} \mathrm{O} ; 72.5 \mathrm{mg}$ of Fe as $\mathrm{FeSO}_{4} \cdot 7 \mathrm{H}_{2} \mathrm{O} ; 30.75 \mathrm{mg}$ of $\mathrm{Cu}$ as $\mathrm{CuSO}_{4} \cdot 5 \mathrm{H}_{2} \mathrm{O} ; 0.85 \mathrm{mg}$ of I as KI; $0.45 \mathrm{mg}$ of $\mathrm{Co}$ as $\mathrm{CoCl}_{2} \cdot 6 \mathrm{H}_{2} \mathrm{O} ; 0.63 \mathrm{mg}$ of $\mathrm{Se}$ as $\mathrm{Na}_{2} \mathrm{Se} \cdot \mathrm{NO}_{3} ; 3150$ ten thousand IU of vitamin $\mathrm{A} ; 3500 \mathrm{IU}$ of vitamin $\mathrm{D} ; 20$ ten thousand $\mathrm{mg}$ of vitamin $\mathrm{E}$; and $4200 \mathrm{mg}$ of vitamin $\mathrm{K}_{3} .{ }^{(2)}$ Metabolic energy was a calculated value, while the others were measured values; $\mathrm{ME}=(36.21 \times \mathrm{CP}+85.44 \times \mathrm{EE}+37.26 \times \mathrm{NFE}) \times 4.184$.

\subsection{Sample Collection and Parameter Measurement}

The offered and refused feed amounts were recorded on the third and fourth days every other week throughout the entire experimental period. All samples were dried in an oven at $65{ }^{\circ} \mathrm{C}$ for $48 \mathrm{~h}$, ground with a Wiley mill to pass through a 2-mm screen, and then stored in a refrigerator at $-20{ }^{\circ} \mathrm{C}$ for further analyses. The daily feed offered, orts, and spillages were collected and weighed to determine the average daily feed intake. At the 
end of 4th week and 8th week, withers height, body length, and chest girth were measured as quantitative indicators.

At the 7th day, the digestion and metabolism test was conducted at the end of the formal period, in which the first two days were the adaptation period and the last five days were sampled. Fecal samples were collected 3 times a day with an interval of $8 \mathrm{~h}$ for each time. After the collection, $10 \% \mathrm{H}_{2} \mathrm{SO}_{4}$ was added for nitrogen fixation. The 5-day fecal samples (200 g) were mixed and stored in a refrigerator at $-20{ }^{\circ} \mathrm{C}$ for the determination of the apparent digestibility of nutrients. Feed and feces were dried and ground using a pulverizer for the subsequent determination of dry matter, crude protein, neutral detergent fiber, acid detergent fiber, ether extract, and crude ash content. For both TMR and fecal samples, DM was detected using AOAC method 930.15; EE was measured using AOAC method 920.85; CP was tested using the method described by Kjeldahl with an azotometer (Scino KT260, FOSS, Hillerod, Denmark); NDF and ADF were measured using the methods described by Van Soest and a fiber analyzer (2000i, Ankom, New York, NY, USA); and ash content was measured according to AOAC method 938.08 [15].

On the last day of the experiment, the rumen fluid $(250 \mathrm{~mL})$ was collected through an oral collector and filtered with a four-layer sterilized gauze two hours after the morning feeding. The pH (PB-21, Beijing Sartorius Scientific Instrument Co., Ltd., Bejing, China) value was determined immediately. Then, $10 \mathrm{~mL}$ aliquots were added with $0.1 \mathrm{~mL}$ of $6 \mathrm{~mol} / \mathrm{L} \mathrm{HCl}$ and stored at $-20^{\circ} \mathrm{C}$ for the determination of the ammonia-nitrogen concentration according to the method of Weatherburn [16]. Another $10 \mathrm{~mL}$ of ruminal fluid samples were thawed in ultrapure water and centrifuged for $10 \mathrm{~min}$ at $15,000 \times g$, after which supernatants were removed to centrifuge tubes containing $25 \%$ metaphosphoric acid and then stored at $-20{ }^{\circ} \mathrm{C}$ for the analysis of volatile fatty acid concentration using a GC Ultra gas chromatograph (Thermo Fisher Scientific, Waltham, MA, USA) as described by Guo et al. [17]. The yield of crude microbial proteins was determined according to the method described by Hall and Herejk [18].

Jugular blood samples of approximately $10 \mathrm{~mL}$ were collected from each Holstein bull calf in vacuum plasma tubes at $3 \mathrm{~h}$ after the morning feeding on the third day of weeks 4 and 8 [19]. The collected blood was then centrifuged at $3000 \times g$ at $4{ }^{\circ} \mathrm{C}$ for $10 \mathrm{~min}$ to collect serum, which was then frozen at $-20{ }^{\circ} \mathrm{C}$ for further analysis. Serum samples were analyzed for the quantification of the total protein (TP), albumin (ALB), globulin (GLOB), aspartate aminotransferase (AST), alanine aminotransferase (ALT), blood urea nitrogen (BUN), and uric acid (UA) according to methods described in previous studies [20].

The ITC pre-column derivatization method was used to determine glutamate. The specific method was in reference to the research report of J.L. Zhang et al. [21]. The concentration of $\mathrm{NH}_{3}-\mathrm{N}$ in the urine was determined by method of phenol-sodium hypochlorite colorimetry [22].

\subsection{Statistical Analysis}

The numerical data were analyzed by one-way analysis of variance (ANOVA) with orthogonal data and the significance of differences between the groups was determined by Tukey's post-hoc test, assuming significance levels of 0.05 and 0.01 . The tables present the means and standard error of the mean (SEM). The calculations were made using SAS 9.4 software (SAS Institute, Cary, NC, USA).

\section{Results}

\subsection{Influence of BM1259 on the Growth Performance and Body Size of Holstein Bull Calves}

As shown in Table 2, the ADG and DMI of the BMG were significantly higher than those of the control group ( $p<0.01$ ), increased by $12.5 \%$ and $8.79 \%$, respectively, during the 4-8 weeks after the addition of $12 \mathrm{~g} /$ head/day of BM1259; from 0 to 8 weeks, ADG $(p<0.05)$ and DMI $(p<0.05)$ in the BMG were significantly higher than those in the control group, increased by $14.9 \%$ and $6.04 \%$, respectively. The feed conversion rate, withers 
height, body length, and chest girth were higher in the BMG but the differences were not significant $(p>0.05)$.

Table 2. Influence of BM1259 on growth performance and body size of Holstein bull calves.

\begin{tabular}{cccccc}
\hline Item & Time & COG & BMG & SEM & $p$-Value \\
\hline \multirow{3}{*}{ ADG (kg/d) } & 0-4 week & 1.24 & 1.37 & 0.02 & $p<0.05$ \\
& 4-8 week & 1.52 & 1.71 & 0.03 & $p<0.01$ \\
& 0-8 week & 1.34 & 1.54 & 002 & $p<0.05$ \\
DMI (kg/d) & 0-4 week & 4.58 & 4.68 & 0.04 & 0.23 \\
& 4-8 week & 6.03 & 6.56 & 0.05 & $p<0.01$ \\
& 0-8 week & 5.30 & 5.62 & 0.03 & $p<0.05$ \\
FCR & 0-4 week & 3.75 & 3.44 & 0.10 & 0.05 \\
& 4-8 week & 4.00 & 3.88 & 0.11 & 0.46 \\
WH (cm) & 0-8 week & 4.02 & 3.67 & 0.12 & 0.06 \\
& 4th weekend & 93.10 & 94.60 & 0.75 & 0.89 \\
BL (cm) & 8th weekend & 136.90 & 142.30 & 2.19 & 0.37 \\
CG (cm) & 4th weekend & 91.50 & 106.10 & 1.15 & 0.39 \\
& 8th weekend & 147.70 & 158.50 & 1.84 & 0.73 \\
4th weekend & 161.50 & 173.80 & 2.50 & 0.83 \\
\hline Ath weekend & 175.00 & 199.60 & 2.15 & 0.32 \\
\hline
\end{tabular}

Abbreviations: COG, control group; BMG, bacillus megatherium group; SEM, standard error of the mean; ADG average daily gain; DMI, dry matter intake; FCR, feed conversion rate; $\mathrm{WH}$, withers height; $\mathrm{BL}$, body length; and CG, chest girth.

\subsection{Effects of BM1259 on the Nutrient Apparent Digestibility of Holstein Bull Calves}

As is presented in Table 3, at the end of the fourth week, the apparent digestibility of $\mathrm{CP}$ and NDF in the BMG was significantly higher than that in the COG $(p<0.05)$, increased by $5.97 \%$ and $6.70 \%$, respectively, after adding $12 \mathrm{~g} /$ head/day of BM1259. At the end of the eight week, the apparent digestibility of $\mathrm{CP}$ and NDF was significantly higher than that of the control group $(p<0.01)$, increased by $5.88 \%$ and $10.26 \%$, respectively. Compared with the COG, the apparent digestibility of ADF and EE in the BMG was higher but there was no significant difference $(p>0.05)$.

Table 3. Effects of BM1259 on the nutrient apparent digestibility of Holstein bull calves.

\begin{tabular}{cccccc}
\hline Item & Time & COG & BMG & SEM & $p$-Value \\
\hline \multirow{2}{*}{ CP (\%) } & 4th weekend & 59.93 & 63.51 & 0.86 & $p<0.05$ \\
& 8th weekend & 61.40 & 65.01 & 0.45 & $p<0.01$ \\
NDF (\%) & 4th weekend & 53.70 & 57.30 & 0.93 & $p<0.05$ \\
& 8th weekend & 55.67 & 61.38 & 0.85 & $p<0.01$ \\
ADF (\%) & 4th weekend & 45.56 & 48.36 & 0.83 & 0.05 \\
& 8th weekend & 49.94 & 51.65 & 0.80 & 0.07 \\
EE (\%) & 4th weekend & 71.33 & 72.48 & 2.32 & 0.74 \\
& 8th weekend & 73.03 & 75.65 & 1.68 & 0.30 \\
\hline
\end{tabular}

Abbreviations: $\mathrm{CP}$, crude protein; NDF, neutral detergent fiber; $\mathrm{ADF}$, acid detergent fiber; and EE, ether extract.

\subsection{Influence of BM1259 on the Rumen Fermentation Parameters}

As is shown in Table 4, at the end of the eight week, the rumen fluid $\mathrm{pH}(p<0.05)$, microbial protein $(p<0.05)$, and acetate $(p<0.05)$ in the BMG were significantly higher than those in the COG, increased by $9.03 \%, 19.68 \%$, and $12.74 \%$, respectively, after adding $12 \mathrm{~g} /$ head/day of BM1259. At the end of the fourth and eighth week, $\mathrm{NH}_{3}-\mathrm{N}$ concentration in the BMG was significantly lower than that in the COG, with a decrease of $21.81 \%$ and $16.40 \%$, respectively. The content of sulfuretted hydrogen, total volatile fatty acids, propionate, butyrate, and acetate:propionate showed no significant differences between the COG and BMG at each stage of experiment $(p>0.05)$. 
Table 4. Influence of BM1259 on the rumen fermentation parameters of Holstein bull calves.

\begin{tabular}{cccccc}
\hline Item & Time & COG & BMG & SEM & $p$-Value \\
\hline \multirow{2}{*}{$\mathrm{PH}$} & 4th weekend & 6.33 & 6.45 & 0.07 & 0.35 \\
& 8th weekend & 6.20 & 6.76 & 0.05 & $p<0.05$ \\
$\mathrm{NH}_{3}-\mathrm{N}(\mathrm{mg} / \mathrm{dL})$ & 4th weekend & 10.82 & 8.46 & 0.18 & $p<0.01$ \\
& 8th weekend & 14.39 & 12.03 & 0.82 & $p<0.01$ \\
$\mathrm{MCP}(\mathrm{mg} / \mathrm{mL})$ & 4th weekend & 2.23 & 2.63 & 0.05 & $p<0.05$ \\
& 8th weekend & 2.49 & 2.98 & 0.05 & $p<0.05$ \\
$\mathrm{H}_{2} \mathrm{~S}(\mathrm{nmol} / \mathrm{mL})$ & 4th weekend & 14.11 & 12.55 & 1.09 & 0.32 \\
& 8th weekend & 13.5 & 12.11 & 0.69 & 0.16 \\
$\mathrm{TVFA}(\mathrm{mmol} / \mathrm{L})$ & 4th weekend & 95.88 & 113.29 & 6.85 & 0.06 \\
& 8th weekend & 99.60 & 107.34 & 3.41 & 0.45 \\
Acetate & 4th weekend & 53.69 & 66.83 & 3.44 & $p<0.05$ \\
$(\mathrm{C} 2)(\mathrm{mmol} / \mathrm{L})$ & 8th weekend & 56.69 & 63.91 & 2.44 & $p<0.05$ \\
$\mathrm{Propionate}(\mathrm{C} 3)$ & 4th weekend & 24.18 & 28.74 & 1.94 & 0.12 \\
(mmol/L) & 8th weekend & 24.94 & 27.07 & 1.46 & 0.31 \\
Butyrate(C4) & 4th weekend & 12.19 & 15.77 & 1.21 & 0.06 \\
(mmol/L) & 8th weekend & 12.18 & 13.76 & 0.89 & 0.24 \\
C2:C3 & 4th weekend & 2.27 & 2.43 & 0.16 & 0.48 \\
& 8th weekend & 2.36 & 2.46 & 0.21 & 0.36
\end{tabular}

Abbreviation: MCP, microbial protein; TVFA, total volatile fatty acids; $\mathrm{C} 2$, acetate; $\mathrm{C} 3$, propionate; and $\mathrm{C} 4$ butyrate.

\subsection{Effect of BM1259 on the Contents of Glutamate in the Rumen Fluid, Serum, Feces, and Urine}

In this study, in order to explore the effects of adding $12 \mathrm{~g} / \mathrm{head} /$ day of BM1259 on the glutamate content, the glutamate content was measured in the rumen fluid, serum, feces, and urine of the Holstein bull calves in the BMG and COG (Table 5). Results demonstrated that at the end of the fourth $(p<0.05)$ and eighth week $(p<0.05)$, the glutamate content of the rumen fluid in the BMG was significantly higher than that in the COG, increased by $13.21 \%$ and $14.32 \%$, respectively; at the end of the fourth week, the contents of glutamate in the serum $(p<0.05)$, urine $(p<0.05)$, and feces $(p<0.05)$ of the Holstein bull calves in the BMG were significantly lower than those in the COG, decreased by $25.76 \%, 33.87 \%$, and $9.23 \%$, respectively; at the end of the eighth week, the contents of glutamate in the serum, urine, and feces in the BMG were significantly lower than those in the COG $(p<0.01)$, decreased by $26.69 \%, 27.94 \%$, and $11.11 \%$, respectively.

Table 5. Effect of BM1259 on the contents of glutamate in the rumen fluid, serum, feces, and urine of Holstein bull calves.

\begin{tabular}{cccccc}
\hline Item & Time & COG & BMG & SEM & $p$-Value \\
\hline \multirow{2}{*}{ Rumen fluid $(\mathrm{g} / 100 \mathrm{~mL})$} & 4 weekend & 3.86 & 4.37 & 0.15 & $p<0.05$ \\
& 8 weekend & 4.19 & 4.79 & 0.17 & $p<0.05$ \\
Serum $(\mathrm{g} / 100 \mathrm{~mL})$ & 4 weekend & 3.30 & 2.45 & 0.11 & $p<0.05$ \\
& 8 weekend & 3.41 & 2.50 & 0.09 & $p<0.01$ \\
Urine $(\mathrm{g} / 100 \mathrm{~mL})$ & 4 weekend & 0.62 & 0.41 & 0.03 & $p<0.05$ \\
& 8 weekend & 0.68 & 0.49 & 0.03 & $p<0.01$ \\
Feces $(\mathrm{mg} / \mathrm{g} \mathrm{DM})$ & 4 weekend & 0.65 & 0.59 & 0.02 & $p<0.05$ \\
& 8 weekend & 0.72 & 0.64 & 0.03 & $p<0.01$ \\
\hline
\end{tabular}

\subsection{Effects of BM1259 on the Content of $\mathrm{H}_{2} \mathrm{~S}$ and Ammonia-Nitrogen in Urine}

As is shown in Table 6, by adding $12 \mathrm{~g} /$ head/day of BM1259, the urine ammonianitrogen content of the BMG was extremely significantly lower than that of the COG at the end of the fourth and eighth week $(p<0.01)$, decreased by $54.60 \%$ and $40.31 \%$, respectively. $\mathrm{H}_{2} \mathrm{~S}$ content in the urine of the BMG decreased overall but there was no significant difference between the two groups $(p>0.05)$. 
Table 6. Effects of BM1259 on the content of $\mathrm{H}_{2} \mathrm{~S}$ and ammonia-nitrogen in urine.

\begin{tabular}{cccccc}
\hline Item & Time & COG & BMG & SEM & $p$-Value \\
\hline \multirow{2}{*}{$\mathrm{NH}_{3}-\mathrm{N}(\mathrm{mg} / \mathrm{dL})$} & 4th weekend & 1.74 & 0.79 & 0.16 & $p<0.01$ \\
& 8th weekend & 1.91 & 1.14 & 0.13 & $p<0.01$ \\
$\mathrm{H}_{2} \mathrm{~S}(\mathrm{nmol} / \mathrm{mL})$ & 4th weekend & 7.79 & 6.78 & 1.39 & 0.36 \\
& 8th weekend & 7.36 & 7.12 & 0.81 & 0.21 \\
\hline
\end{tabular}

\subsection{Effect of BM1259 on the Blood Biochemical Parameters of Holstein Bull Calves}

As is presented in Table 7, compared with the COG, adding $12 \mathrm{~g} /$ head / day of BM1259 had no significant effect on the level of blood biochemical parameters of Holstein bull calves.

Table 7. Effect of BM1259 on the blood biochemical parameters of Holstein bull calves.

\begin{tabular}{cccccc}
\hline Item & Time & COG & BMG & SEM & $p$-Value \\
\hline \multirow{2}{*}{ ALT(U/L) } & 4th weekend & 28.76 & 21.92 & 3.81 & 0.14 \\
& 8th weekend & 24.76 & 25.84 & 3.74 & 0.48 \\
AST(U/L) & 4th weekend & 85.84 & 85.61 & 8.82 & 0.05 \\
& 8th weekend & 84.15 & 94.46 & 8.58 & 0.09 \\
TP (g/L) & 4th weekend & 63.68 & 61.99 & 7.40 & 0.57 \\
& 8th weekend & 64.56 & 64.72 & 4.87 & 0.94 \\
ALB (g/L) & 4th weekend & 28.12 & 27.86 & 1.38 & 0.64 \\
GLO (g/L) & 8th weekend & 29.12 & 29.72 & 0.69 & 0.32 \\
& 4th weekend & 35.56 & 34.13 & 6.70 & 0.60 \\
BUN (mmoI/L) & 8th weekend & 35.44 & 35.00 & 4.19 & 0.79 \\
\multirow{2}{*}{ 4A (mmoI/L) } & 8th weekend & 5.38 & 5.49 & 1.40 & 0.85 \\
& 4th weekend & 3.44 & 3.94 & 1.20 & 0.30 \\
& 8th weekend & 27.84 & 28.30 & 2.70 & 0.96 \\
\hline
\end{tabular}

Abbreviations: ALT, alanine transaminase; AST, aspartate transaminase; TP, total protein; ALB, albumin; GLO, globulin; BUN, blood urea nitrogen; and UA, uric acid.

\section{Discussion}

It was found that adding bacillus to the diet of Holstein bull calves could improve the performance of Holstein bull calves. Youssef et al. showed that feeding bacillus subtilis BSN fermentation significantly improved the feed conversion rate and milk yield but had no significant effects on the milk fat percentage and milk protein percentage [23]. Hu et al. demonstrated that feeding $1.0 \times 10^{10} \mathrm{cfu} / \mathrm{g}$ bacillus subtilis improved the milk yield of Holstein cows by $11.61 \%$ [24]. Deng et al. found that feeding bacillus natto significantly increased the milk yield of $4 \%$ milk fat [25]. It was found that the addition of $12 \mathrm{~g} / \mathrm{head} /$ day of BM1259 could significantly improve the growth performance and rumen fermentation ability, and there was no significant difference in the blood biochemical parameters. In our study, the ADG and DMI were significantly increased but there were no significant differences in FCR, WH, and BL. During the growth and metabolism of bacillus, some digestive enzymes with strong activity can be produced, such as protease, lipase, and starch hydrolase, which can decompose some complex carbohydrates such as gum and xylan, so as to promote the digestion and absorption capacity of nutrients in the rumen [26]. In this study, we found that supplementation of $12 \mathrm{~g} /$ head/day of BM1259 could significantly improve the digestion and utilization ratio of $\mathrm{CP}$ and glutamate, which was related to 12 coding genes related to nitrogen metabolism in our previous research. In addition, the digestion and utilization rate of NDF were significantly improved after the addition of $12 \mathrm{~g} /$ head/day of BM1259, which might be due to the secretion of certain digestive enzymes that promoted the decomposition and digestion of NDF.

The rumen $\mathrm{pH}$ value is one of the evaluation parameters of rumen microbial growth, metabolism balance, and fermentation degree, which is mainly affected by the amount of saliva buffer secretion of ruminants [27]. The rumen fibro lytic bacteria had the highest 
activity at $\mathrm{pH} 6.7$ and the rumen degradability and acetate content decreased with the decrease of $\mathrm{pH}$ [28-30]. In this study, after adding $12 \mathrm{~g} /$ head/day of BM1259, the rumen $\mathrm{pH}$ value increased significantly from 6.20 to 6.76 after eight weeks. The results indicated that adding a certain amount of BM1259 could promote the growth of fibro lytic bacteria. $\mathrm{NH}_{3}-\mathrm{N}$ is the main nitrogen source (about 20-100\%) in the process of rumen microbial flora growth and reproduction of ruminants. The concentration of $\mathrm{NH}_{3}-\mathrm{N}$ should be moderate in order to facilitate microbial growth and promote microbial MCP generation. Too high or too low concentration is not suitable for microbial growth [31-33]. In this study, it was found that the rumen $\mathrm{NH}_{3}-\mathrm{N}$ concentration was significantly decreased after the addition of $12 \mathrm{~g} /$ head/day of BM1259, which was in the range of $8.46-12.03 \mathrm{mg} / \mathrm{dL}$, although lower than that of the $10 \mathrm{~g} /$ head/day of BM1259 (15.95-25.32 mg/dL) in Yu [34]. However, dietary supplementation of BM1259 has a certain influence on the rumen ammonia-nitrogen $\mathrm{NH}_{3}-\mathrm{N}$ concentration. VFA is one of the energy substances used to maintain the normal life activities of ruminants, which can provide more than $70 \%$ of the digestive energy and participate in different metabolisms in the body [35]. Diana et al. found that by feeding bacillus subtilis, C2 concentration and C2:C3 were significantly decreased, while TVFA, C3, and $\mathrm{NH}_{3}-\mathrm{N}$ contents were significantly increased [36]. Ding et al. found that the $\mathrm{C} 2: \mathrm{C} 3$ could be significantly reduced and both the TVFA and C 3 content could be increased with supplementation of bacillus subtilis in the fermentation test [37]. However, our results demonstrated that after the addition of BM1259, the C2 concentration increased significantly and the $\mathrm{C} 2: \mathrm{C} 3$ increased, indicating that the rumen fermentation type changed to acetate fermentation, which was consistent with the significant increase in the content of Saccharofermentans in our previous study [2]. The levels of $\mathrm{NH}_{3}-\mathrm{N}$ and $\mathrm{H}_{2} \mathrm{~S}$ in the urine not only affected the health of the livestock and humans, but also reflected the nitrogen utilization capacity of animals [38]. In this study, after the addition of $12 \mathrm{~g} / \mathrm{head} /$ day of BM1259, $\mathrm{NH}_{3}-\mathrm{N}$ in the urine of Holstein bull calves significantly decreased and the content of $\mathrm{H}_{2} \mathrm{~S}$ in the excreta was significantly reduced.

The level of the blood biochemical parameters can reflect the status of nutrient metabolism and the acid-base balance of the animal body to a certain extent. Meanwhile, the level of serum albumin and total protein is an indicator for measuring the health status of the animal [39-41]. In this study, it was found that after adding $12 \mathrm{~g} /$ head/day of BM1259, most biochemical parameters in the blood of Holstein bull calves did not significantly change, indicating that BM1259 did not have adverse effects on the body health status.

\section{Conclusions}

In summary, the addition of BM1259 to the diets of Holstein bull calves can significantly improve the growth performance and elevate the apparent digestibility of $\mathrm{CP}$ and NDF. Moreover, supplementation with BM1259 increased C2 and C2:C3 in the rumen, and reduced emission of $\mathrm{NH}_{3}-\mathrm{N}$ and $\mathrm{H}_{2} \mathrm{~S}$ in the feces and urine, indicating a possible amelioration in the rumen fermentation and nitrogen utilization. In addition, adding $12 \mathrm{~g} /$ head/day of BM1259 had no adverse effect on blood biochemical parameters and health status. However, further research is necessary to uncover the mechanism by which BM1259 improves nitrogen utilization in Holstein bull calves.

Author Contributions: B.D. conceived the project; B.D. and Y.C. wrote the manuscript; Y.C., X.G. and B.D. conducted the animal experiment; Y.D. provided the BM1259 strain; Y.C., K.Z., M.L., L.W. and G.Z. reviewed and edited the manuscript. All authors have read and agreed to the published version of the manuscript.

Funding: This research was funded by the Jiangsu Province Post-Doctoral Foundation (C); the Research Project of Dairy Bioengineering Technology Research Center of Jiangsu Province (2019); the Research Project of Natural Science Foundation of Jiangsu Province (BK20190898); the National Natural Science Foundation of China (number 31972589); and the China Agriculture Research System of MOF and MARA. 
Institutional Review Board Statement: The study was conducted following the guidelines approved by the Institutional Animal Care and Use Committee (SYXK (Su) IACUC 2016-0019) regulations.

Informed Consent Statement: Not applicable.

Data Availability Statement: Not applicable.

Conflicts of Interest: The authors declare no conflict of interest.

\section{References}

1. Chen, L.; Zhou, C.; Liu, G. Application of lactic acid bacteria, yeast and bacillus as feed additive in dairy cattles. J. Food Agric. Environ. 2013, 11, 626-629.

2. Deng, B.; Wang, L.; Ma, Q. Genomics Analysis of Bacillus megaterium 1259 as a Probiotic and Its Effects on Performance in Lactating Dairy Cows. Animals 2021, 11, 397. [CrossRef] [PubMed]

3. Peng, H.; Wang, J.Q.; Kang, H.Y. Effect of feeding Bacillus subtilis natto fermentation product on milk production and composition, blood metabolites and rumen fermentation in early lactation dairy cows. J. Anim. Physiol. Anim. Nutr. 2012, 96, 506-512. [CrossRef] [PubMed]

4. Vary, P.S.; Biedendieck, R.; Fuerch, T. Bacillus megaterium-From simple soil bacterium to industrial protein production host. Appl. Microbiol. Biot. 2007, 76, 957-967. [CrossRef] [PubMed]

5. De Vos, P. Bergey's Manual of Systematic Bacteriology, Volume 3: The Firmicutes; Springer: New York, NY, USA, 2009.

6. Weili, Z.; Yu, L.; Xiao, T. Comparison of BM1259 and yucca extract on ammonia nitrogen emission of manure during storage period in laying hens. Feed Ind. 2014, 35, 13-16. (In Chinese)

7. Biedendieck, R.; Bunk, B. Systems biology of recombinant protein production in Bacillus megaterium. Adv. Biochem. Eng. Biotechnol. 2010, 120, 133-161.

8. Biedendieck, R.; Yang, Y. Plasmid system for the intracellular production and purification of affinity-tagged proteins in Bacillus megaterium. Biotehnol. Bioeng. 2007, 96, 525-537. [CrossRef]

9. Christie, G.; Gotzke, H. Identification of a receptor subunit and putative ligand-binding residues involved in the Bacillus megaterium QM B1551 spore germination response to glucose. J. Bacteriol. 2010, 192, 4317-4326. [CrossRef]

10. Agrahari, S.; Wadhwa, N. Isolation and characterization of feather degrading enzymes from Bacillus megaterium SN1 isolated from Ghazipur poultry waste site. Prikl. Biokhimiia I Mikrobiol. 2012, 48, 199-205. [CrossRef]

11. Kritas, S.K.; Christodoulopoulos, G. Effect of Bacillus licheniformis and Bacillus subtilis supplementation of ewe's feed on sheep milk production and young lamb mortality. J. Vet. Med. A Physiol. Pathol. Clin. Med. 2006, 53, 170-173. [CrossRef]

12. Huo, Y.J.; Gong, X.X. Effects of Bacillus subtilis 1259 on performance and ammonia production in pig manure. Jiangsu Agric. Sci. 2012, 40, 159-161.

13. Ding, W.J.; Wang, Q. Effects of Bacillus megatherium 1259 on performance and fecal nitrogen concentration of laying hens. Chin. J. Anim. Nutr. 2015, 27, 3140-3145.

14. Yu, T.S. Effects of Bacillus megatherium on Performance, Rumen Fermentation and Biochemical Indices of Lactation Cows. Master's Thesis, Yangzhou University, Yangzhou, China, May 2016.

15. Van Soest, P.J. Nutritional Ecology of the Ruminant; Cornell University Press: New York, NY, USA, 1994.

16. Seta, F.R.; Tamagno, B.E. Trichloramine-nitrite reaction for determination of blood ammonia. Anal. Chem. 1970, 42, 1443-1445. [CrossRef]

17. Guo, W.S.; Schaefer, D.M. Use of nitrate-nitrogen as a sole dietary nitrogen source to inhibit ruminal methanogenesis and to improve microbial nitrogen synthesis in vitro. Asian Australas. J. Anim. Sci. 2009, 22, 542-549. [CrossRef]

18. Hall, M.B.; Herejk, C. Differences in yields of microbial crude protein from in vitro fermentation of carbohydrates. J. Dairy Sci. 2001, 84, 2486-2493. [CrossRef]

19. Wang, D.M.; Wang, C. Effects of rumen-protected $\gamma$-aminobutyric acid on feed intake, lactation performance, and antioxidative status in early lactating dairy cows. J. Dairy Sci. 2013, 96, 3222-3227. [CrossRef]

20. Davidson, S.; Odle, J. Supplementing limited methionine diets with rumen-protected methionine, betaine, and choline in early lactation Holstein cows. J. Dairy Sci. 2008, 91, 1552-1559. [CrossRef]

21. Zhang, J.L.; Sun, J.Y. Analysis of plasma free amino acids by high performance liquid chromatography-PITC derivation. J. Kunming Med. Coll. 1994, 2, 28-33.

22. Maiteseidi, T.; Yibureyimu, A. Determination of ammonia-nitrogen concentration in rumen fluid treated with methanol by sodium hypochlorite and phenol spectrophotometry. Xinjiang Agric. Sci. 2012, 3, 179-184.

23. Youssef, N.; Sheik, C.S.; Krumholz, L.R. Comparison of Species Richness Estimates Obtained Using Nearly Complete Fragments and Simulated Pyrosequencing-Generated Fragments in $16 \mathrm{~S}$ rRNA Gene-Based Environmental Surveys. Appl. Environ. Microbiol. 2009, 75, 5227-5236. [CrossRef]

24. Hu, H.L.; Zhang, B. Effects of Bacillus subtilis microecologics on dairy cows' diets. Feed Ind. 2011, 18, 52-55.

25. Deng, L.F. Effects of Dietary Addition of Bacillus subtilis on Performance, Rumen Fermentation and Functional Microorganisms of Dairy Cows [D]. Ph.D. Thesis, Chinese Academy of Agricultural Sciences, Beijing, China, June 2009.

26. Wan, G.F. Microecological agents and their application in chicken industry. Biol. Teach. 2009, 34.001, 6-8. 
27. Saro, C.; Ranilla, M.J.; Tejido, M.L. Influencn fermentation and functional microorganisms of dairy cows. Chin. Acad. Agric. Sci. $\mathrm{Ph} . \mathrm{D}$. Thesis, May e of forage type in the diet of sheep on rumen microbiota and fermentation characteristics. Livest. Sci. 2014, $160,52-59$

28. Li, H.W.; Wang, Q.P. Ruminal Fermentation: A Review of CNCPS Research. Anim. Husb. Feed Sci. 2011, 32, 31-36.

29. McDonald, P. Animal Nutrition, 5th ed.; Longman: London, UK, 1995.

30. Leng, R.A.; Leonard, G.J. Measurement of the rates of production of acetic, propionic and butyric acids in the rumen of sheep. Br. J. Nutr. 1965, 19, 469-484. [CrossRef]

31. Anantasook, N.M.; Wanapat, M. Effect of plants containing secondary compounds with palm oil on feed intake, digestibility, microbial protein synthesis and microbial population in dairy cows. J. Anim. Sci. 2013, 26, 820-826. [CrossRef]

32. Khan, M.A.; Lee, H.J. Starch Source Evaluation in Calf Starter: II. Ruminal Parameters, Rumen Development, Nutrient Digestibilities, and Nitrogen Utilization in Holstein Calves. J. Dairy Sci. 2008, 91, 1140-1149. [CrossRef]

33. Bach, A. Nitrogen Metabolism in the Rumen. J. Dairy Sci. 2005, 88, E9-E21. [CrossRef]

34. Weimer, P.J.; Yan, S. A segmented gas/liquid delivery system for continuous culture of microorganisms on insoluble substrates and its use for growth of Ruminococcus flavefaciens on cellulose. Appl. Microbiol. Biotechnol. 1991, 36, 178-183. [CrossRef]

35. Van Houtert, M. Challenging the retinal for altering VFA ratios in growing ruminates. Feed Mix 1996, 4, 8-12.

36. Diana, V.; Arthur, O. Rapid sampling for analysis of in vivo kinetics using the BioScope: A system for continuous-pulse experiments. Biotechnol. Bioeng. 2002, 79, 674-681.

37. Ding, H.T.; Xia, D.H. Effects of Bacillus subtilis on in vitro rumen fermentation of dairy cows. Feed Res. 2012, 36, 33-39.

38. Tza, B.; Lin, L. Factors impacting the performance and microbial populations of three biofilters for co-treatment of $\mathrm{H}_{2} \mathrm{~S}$ and $\mathrm{NH}_{3}$ in a domestic waste landfill site-ScienceDirect. Process Saf. Environ. Prot. 2021, 149, 410-421.

39. Whitaker, D.A. Interpretation of metabolic profiles in dairy cows. Cattle Pract. 1997, 5, 57-60.

40. Ceapa, C.; Wopereis, H. Influence of fermented milk products, prebiotics and probiotics on microbiota composition and health Best Pract. Res. Clin. Gastroenterol. 2013, 27, 139-155. [CrossRef] [PubMed]

41. Silas, G.V.B.; Daniel, G.D. Simultaneous analysis of amino and nonamino organic acids as methyl chloroformate derivatives using gas chromatography-mass spectrometry. Anal. Biochem. 2003, 322, 134-138. 